\title{
Heat-Stable Enterotoxin Receptor
}

National Cancer Institute

\section{Source}

National Cancer Institute. Heat-Stable Enterotoxin Receptor. NCI Thesaurus. Code

C123877.

Heat-stable enterotoxin receptor (1073 aa, $123 \mathrm{kDa}$ ) is encoded by the human GUCY2C gene. This protein is involved in ligand-stimulated guanylate cyclase activity. 